\title{
$O$ ano de 1993 ou o encontro dos tempos, dentro e fora da revolução
}

\section{$O$ ano de 1993 or the meeting of the times, inside and outside the revolution}

\author{
Pedro Fernandes de Oliveira Neto ${ }^{1}$
}

\begin{abstract}
Resumo
O ano de 1993 é sempre tratado à parte na literatura de José Saramago ou como testamento entre dois instantes de organização de sua dicção poética. Este texto repassa essa determinante ressaltando aspectos temáticos que seriam parte da obra anterior e posterior ao livro de 1975. Dentre eles, privilegia o tema da revolução, demonstrado como um instante de transformação coletiva capaz de romper com o tempo de falibilidade dos processos civilizatórios. Esta matéria encontra amparo na literatura do próprio escritor, no contexto de referência da obra e no estreito diálogo estabelecido com outras criações literárias - especificamente o conjunto de poemas $O$ ano de 1905, de Boris Pasternak, com o qual 1993 parece estimular laços de mais variada ordem. Isso significa que a leitura aqui proposta se sustenta pelo tratamento interpretativo, crítico e analítico-comparativo. Seu alcance finda por materializar os traços compositivos de um livro que é simultaneamente produto contrário às ideologias de um tempo escuro da história e parábola sobre nossa múltipla natureza, situando-se no intervalo das dicotomias que a define, na sua parcela sensível e primitiva que aspira à liberdade e se eleva contra os modelos de dominação estabelecidos pela própria força humana.
\end{abstract}

Palavras-chave: José Saramago. Literatura. História. Revolução.

\begin{abstract}
O Ano de 1993 is always treated separately in José Saramago's literature or as a testament between two moments of organization of his poetic diction. This text reviews this determinant, emphasizing thematic aspects that would be part of the work before and after the 1975 book. Among them, it privileges the theme of the revolution, demonstrated as an instant of collective transformation capable of breaking with the time of fallibility of the civilizing processes. This subject finds support in the writer's own literature, in the context of reference of the work and in the close dialogue established with other literary creations - specifically the set of poems O Ano de 1905, by Boris Pasternak, with which 1993 seems to stimulate more varied ties order. This means that the reading proposed here is supported by interpretative, critical and analytical-comparative treatment. Its scope ends by materializing the compositional traits of a book that is simultaneously a product contrary to the ideologies of a dark time in history and a parable about our multiple nature, standing in the range of dichotomies that define it, in its sensitive and primitive portion that aspires to freedom and rises against the models of domination established by human force itself.
\end{abstract}

Keywords: José Saramago. Literature. History. Revolution.

\footnotetext{
${ }^{1}$ Doutorado em Estudos da Linguagem pela Universidade Federal do Rio Grande do Norte (UFRN), Natal, Rio Grande do Norte, Brasil. Professor da Universidade Federal do Rio Grande do Norte, Natal, Rio Grande do Norte, Brasil. E-mail: pedro.letras@yahoo.com.br
} 
Sinal de que talvez nos reconheça enfim a vida e de que nem tudo se perdeu nas abjecções que consentimos algumas vezes cúmplices

(SARAMAGO, 2007, p. 111).

O livro que eu amo e que os reis e seus cortesãos detestam, é o livro que faz nascer os

Brutus

(DIDEROT, 1995, p. 772).

\section{Introdução}

Não importa que Saramago tivesse sido tão mau poeta se emprestou a voz necessária para os dias de 1974. O episódio histórico da Revolução dos Cravos encontra-se materializado de forma muito diversa na literatura do escritor português. Especificamente, o encontramos em Manual de pintura e caligrafia e Levantado do chão, dois dos seus primeiros romances, cujas narrativas evidenciam episódios e situações ancorados nos longos anos que antecederam o acontecimento mais marcante da história de Portugal no século XX. Entre um livro e outro, escreveu a convite de Luzia Maria Martins a peça de teatro $A$ noite, encenada pelo Grupo de Teatro de Campolide; aqui, toda a ação dramática circunscrita numa redação de jornal se desenvolve na noite do dia 24 para o 25 de abril e se concentra nos impasses entre a permanência da ditadura e as suspeitas da Revolução.

A decisão dos redatores da peça de 1978 bem poderia ser designada por $O$ ano de 1993. A incerteza sobre o levante do dia seguinte faz com que estes se decidam por duas edições para o jornal: uma sem as notícias corriqueiras sobre o regime e outra sobre a possibilidade de um levante contra o governo. No livro em questão, assistimos uma sociedade que testemunha sua submissão ao estamento do mal e o ensaio de uma libertação pintada com as cores da restituição de um paraíso perdido. Ora, figura ativa entre os acontecimentos políticos de então, seja porque integrado ao Partido Comunista Português, ao qual se filiou a 16 de janeiro de 1969, seja porque estava no centro das atividades jornalísticas, é possível vislumbrar o escritor no olho de um impasse ao mesmo tempo que envolvido pela cobrança nascida no dia posterior à revolução sobre os livros que o regime havia feito engavetar.

Os registros sobre o envolvimento de José Saramago com a escrita do livro que é publicado pela editora Futura datam de exatamente um ano antes do seu aparecimento; um dia depois do Levantamento de Caldas da Rainha o escritor compôs a primeira das trinta seções que constituem a obra $^{2}$. Ao estabelecer relações criativas entre $O$ ano de 1993 e 1984 de George Orwell, possivelmente o primeiro livro que logo alcança a presença dos leitores de José Saramago, Luciana StegagnoPicchio, reconhecendo as diferenças macroscópicas entre a visão de mundo dos dois criadores, supõe que se processou com Saramago o mesmo que com o escritor inglês: este, invertendo os dois últimos algarismos de 1948, o ano de escrita e a que se refere os horrores totalitários investidos pela ficção, encontrara o título do seu romance; o autor português, por sua vez, repetiria o jogo com 1939, "um ano trágico para a Península Ibérica, quando Portugal reconheceu o governo do general Franco e assinou com a Espanha o tratado de amizade e não agressão" (PICCHIO, 2000, p. 355).

$\mathrm{E}$, caso ou acaso, o que aqui compreendemos é que este ficou sendo, antecipadamente, o livro da Revolução. É que acabada a ditadura, os livros engavetados, pela simples razão de não existirem, nunca apareceram; e embora o episódio histórico

${ }^{2}$ Assim esclarece em entrevista para o jornal Extra, em 1978: "comecei a escrevê-lo antes do 25 de abril, precisamente no dia da tentativa militar das Caldas da Rainha. Foi por desespero que o principiei. Depois veio a Revolução, e o livro pareceu ter perdido o sentido." (SARAMAGO, 1978). 
seja um dos mais referidos na literatura portuguesa pós-1974, também o grande romance sobre esse acontecimento ficou por escrever. $O$ ano de 1993 é publicado e a menos de um mês veio o 25 de Abril. Assim, os horrores do salazarismo e os ventos da Revolução dos Cravos constituem, no primeiro instante, os elementos da atmosfera criativa - reside nisso a diferenciação levantada por StegagnoPicchio (2000): Orwell, ao contrário de Saramago, nunca foi um entusiasta das revoluções socialistas. Mais tarde, sabemos que as determinantes de 1993 não são apenas as situações do calor da hora nas quais se encontra implicado o escritor.

O próprio José Saramago terá se aproximado do desencanto orwelliano quando descobriu, com os de toda uma geração, que os regimes de mando e o próprio fascismo não desapareceram com as reviravoltas históricas, políticas e ideológicas, que o levante deixou de ser um estágio por alcançar, a experiência utópica, para se tornar exercício perene, atemporal e universal na história da luta contra a opressão. Nesse sentido, O ano de 1993 angariou o estatuto de parábola. Quer dizer, é uma história sobre o passado de dominadores e dominados e sobre o futuro de libertação do homem. No prefácio que escreveu para a edição italiana, uma década mais tarde, "E imortal é a esperança", o escritor português explica que colocou "no futuro a história deste povo, o povo de um país não nomeado, imagem de quantos viveram e vivem sujeitos à tirania" e pensava "que talvez tivesse começado a narrar os últimos sofrimentos dos homens, que lentamente começavam a aprender a felicidade e a alegria", mesmo sabendo "que nenhum de nós um dia permanece na sombra que vai projetando no chão que pisa"3. Antes - e isso é impossível negarsobram os ventos positivos da Revolução, algo que José Saramago encontra, como ficará evidenciado ao longo deste texto, noutro livro, também afeito ao ideal revolucionário, nascido num contexto assemelhado com o português e com título que diríamos tratado nas licenças criativas livremente copiado pelo escritor; falamos sobre o pequeno conjunto de poemas organizado pelo poeta russo Boris Pasternak, O ano de 1905.

É uma consciência posterior a que se assume no texto saramaguiano escrito justamente no ano de referência do livro; o que tomaríamos como o disfarce apropriado uma vez a poesia de Pasternak se encontrar visivelmente circunscrita ao lugar histórico. Mas nessa relação encontramos os indícios para pensar que o trabalho de José Saramago com $O$ ano de 1993 não constituiu, como parece à primeira vista, um acidente de percurso. É comum se repetir, seja entre afirmativas do próprio escritor, seja entre a crítica, que este livro é uma obra à parte no projeto literário do escritor - o que é, como tudo, facilmente questionável. Principalmente porque pode-se nele encontrar, além dos estreitamentos com uma tradição literária, uma variedade de elementos que se distendem por todo seu projeto criativo: o acaso, a visão, a libertação dos oprimidos, a identidade e seus afluentes, os poderes político e econômico, o feminino, a irmanação homem-natureza, o encanto e desencanto com os rumos civilizacionais, o ideário da revolução, a primeira crença numa transformação das coletividades, entre outros. É verdade que seja uma obra sui generis pela força experimental do texto; situado entre a poesia e a prosa, o verbal e o visual, a fabulação futurista, as infiltrações surrealistas pelas invasões oníricas e alegóricas, a fragmentação, a circularidade do protótipo narrativo, a natureza de pastiche do romance de ficção científica, as utopias e distopias, o recurso oralizante da dicção e moralizante da fábula, tudo isso é, a um só tempo, inovador entre as produções literárias de então e se situa a meio-caminho dos recursos e técnicas em aperfeiçoamento desde a estreia literária do escritor e o estilo cuja desenvoltura se deixa perceber a partir de Levantado do chão.

\footnotetext{
3 A tradução no texto é minha. A citação completa é: “Ho spostato nel futuro la storia di questo popolo, il popolo d'un paese mai nominato, immagine di quanti hanno subito e subiscono la tirannide, e pensavo che forse mi ero messo a narrare le ultime sofferenze degli uomi, che lentamente avrebbero appreso la felicità, e sapevo però che niente di noi un giorno rimane sotto l'ombra che ciascuno va proiettando sul suolo che calpesta" (SARAMAGO, 2012, não paginado).
} 
Numa visita à bateia criativa de José Saramago nos anos que antecedem 1975, Horácio Costa reconhece algumas situações variadas que determinam a originalidade e a integração do livro agora analisado no conjunto criativo ao qual pertence. Entre elas está o envolvimento do seu autor com os temas de ficção científica. O estudioso cita alguns textos de Deste mundo e do outro, livro de crônicas, forma na qual se experimentou durante toda a vida, mas principalmente nos anos de formação, cuja referência são algumas das mais importantes peças dessa expressão criativa: "Cada vez mais sós"; "Um azul para Marte"; "O Planeta dos Horrores"; "Os animais doidos de cólera" - este último guarda semelhança até mesmo em nível de argumento, uma vez que o relato decorre no ano de 2968. Nesse mesmo ínterim, é possível ainda filiar o conto "Coisas" publicado na antologia Objecto quase; aqui, se vislumbra um mundo em que homens e coisas assumem lugares invertidos, o que, em 1993, se manifesta pelos pares homens e máquinas. Já quanto às experimentações textuais, o leitor as encontra em "O ouvido", texto da coletânea Poética dos cinco sentidos, e alguns dos poemas de Provavelmente alegria: a fusão dos tecidos da prosa e da poesia e o uso do recurso versicular, por exemplo estão em "A mesa é o primeiro objecto", "É um livro de boa-fé" e "Protopoema".

$\mathrm{Na}$ primeira recensão crítica que se tem notícia sobre $O$ ano de 1993, Ana Hatherly aponta as relações imediatas sugeridas entre o livro e 1984, de George Orwell, mas com o intuito de logo expurgar essas inferências pela incompatibilidade dos gêneros e apontando que "entre essas duas obras há diferenças irredutíveis, como a extensão, o conteúdo ideológico e até mesmo o tema propriamente dito." Para ela, embora possamos dizer que o livro do escritor inglês "como Utopia, se pode formalmente referir até a um Thomas Moore, por outro lado, cabe perfeitamente dentro da moderna classificação de 'literatura de antecipação', necessitando, acima de tudo, duma leitura 'alegórica', enquanto 1993, como texto poético que é, necessita duma leitura 'literal'" (HATHERLY, 1976, p. 87-88). A observação da autora não é apenas facilmente questionável porque o alegórico e literal não são distintivos das formas tratadas como é mesmo contraditório na sua leitura, já que, noutra passagem no mesmo texto em referência, acentua a força atemporal do livro de José Saramago, observação que é certamente inauguradora do seu tratamento universalizante. "Esta obra que, escrita em 1974, se lê como um grito contra o estado de sítio da consciência em que viveram os Portugueses", diz, "está marcada por uma experiência que não é só dos últimos cinquenta anos mas a experiência milenária da luta contra a opressão" (HATHERLY, 1976, p. 88).

Entre as referências com a ficção científica, seria válido considerar $O$ ano de 1993 como tributário da Revolução dos bichos, também de George Orwell, por todo levante da cadeia zoomórfica contra os humanos, ou A guerra dos mundos, de H. G. Wells, que Horácio Costa associa à crônica "O planeta dos horrores" e que aqui participa da figuração de uma atmosfera maquínico-opressiva, ou de Admirável mundo novo, de Aldous Huxley, quer pela segmentação social, quer pelo complexo de dominação exercido entre eles, ou de Fahrenheit 451 de Ray Bradbury, pelo controle das vidas por determinações esvaziadas de sentido, ou mesmo de Laranja mecânica de Anthony Burgess, novamente pelo totalitarismo e pelo levante contra o cerco e pelas liberdades individuais e coletivas. As aproximações entre obras, claro está, se operam mais pela linhagem da qual participam todos esses romances, sendo estabelecida ora entre o modelo histórico vigente em seu tempo ora com os livros que o antecederam ora como uma prospecção futurista e, em alguns casos, perene.

O curioso, ao se reparar em todos esses estreitamentos possíveis, é a reiteração das relações - fiáveis, porque se constatam nos escritos de José Saramago como é o caso de sua menção a livros de Ray Bradbury como As crônicas marcianas - é a quase não menção à literatura soviética e russa de onde provém a origem e o designativo do que, só a partir de 1926 passa ser tratado pela crítica estadunidense como ficção científica. Embora se possa atribuir que o começo de tudo está no Frankenstein 
de Mary Shelley (1818), as fábulas do folclore eslavo que estão na base das narrativas fantásticas e das utopias participam da atmosfera criativa de escritores como Gógol e Dostoiévski. No caso de José Saramago, importa ainda mais por razões das mais diversas: sua filiação a uma tradição popular e oral; sua estreita relação, pelo comunismo, com o ideário da revolução, da utopia e da integração no literário das questões históricas, políticas e sociais, contato que se manteve, no tempo de $O$ ano de 1993, com uma vasta produção crítica do ideário socialista e com a literatura russa, das quais, foi tradutor indireto.

Ora, isso significa dizer que o livro de 1975 melhor se filia ao fundador da linhagem distópica Nós, de Ievguêni Zamiátin; este romance publicado no âmbito do chamado ciclo da Revolução Russa de 1917 prefigura o mundo reduzido a uma só sociedade mecanizada e controlada, onde se aboliram as fronteiras do individual pelo coletivo. Como no livro de José Saramago, os habitantes do Estado Único são identificados por números e qualquer desvio é motivo para a pena de morte. Esse sistema é colocado em questão quando num dos que integram essa ordem se reanimam os sentimentos há muito destituídos, semelhante ao que se passa na narrativa possível do escritor português. $\mathrm{O}$ contato entre essas duas obras parece sustentado exclusivamente por um zeitgeist: uma e outra se fazem no calor de uma revolução e uma das inquietações possíveis nesse contexto é sobre como será o futuro a partir de então; as duas obras implicadas no tempo formam assim uma provocação sobre um porvir alimentado pelo fim do desencanto ou reinvenção do encanto, além do encanto de uma humanidade com a contínua expansão tecnológica; as duas testemunham a reabertura dos muitos caminhos estéticos de dois períodos excepcionais da história de cada um dos seus países.

Fiquemos com o tema da revolução. Para Horácio Costa, e com ele concordamos, o livro de José Saramago revela "o desejo de participação política do escritor na época da Revolução dos Cravos" e a projeção ideal ou alegórica segundo suas expectativas ideológicas "parece ser a narração da reconquista redentora que a obra fragmentariamente descreve." (COSTA, 2020, p. 222) Esse interesse, embora sublinhado pelo autor de $O$ periodo formativo não chega a ser desenvolvido - a sua atenção está mais voltada para aspectos formais, estilísticos (e em certa medida temáticos) que detiveram o escritor no tempo anterior ao da escrita de Levantado do chão. É aqui, portanto, que reside o nosso interesse: compreender como $O$ ano de 1993, animado pela ruptura da revolução reaviva seu ideário e constitui uma leitura acerca do tempo que o antecede, isto é, o do desencanto e da ausência de futuro, compreendendo tais questões não como circunscritas ao contexto histórico português em referência mas onipresença na história individual e coletiva dos povos para a liberdade.

\section{O ano de 1993, dentro e fora da revolução}

Se o encontro entre José Saramago com a obra de Ievguêni Zamiátin parece circunscrito apenas no campo das possibilidades e se ocorreu antes da escrita de $O$ ano de 1993 foi indiretamente, não se pode dizer o mesmo com $O$ ano de 1905. O seu autor, Boris Pasternak, então mais famoso que George Orwell, porque recebeu e foi forçado a declinar o Prêmio Nobel de Literatura em 1958, ficou conhecido em língua portuguesa a partir de Portugal; um ano depois de galardoado pela Academia Sueca, a Livraria Bertrand publica a primeira tradução do seu romance mundialmente conhecido, Doutor Jivago, e a Porto Editora, o livro de poemas que foi concebido no calor da Revolução Russa de 1905 e mais de outros rescaldos históricos que se introduziram no imaginário do poeta.

As provadas relações do escritor com a arquitetura da história, do pensamento e da literatura soviética e russa (é de 1959 sua tradução indireta de Anna Kariênina, de Liev Tolstói, publicada pela Estúdios Cor) e a importância nesse âmbito do nome de Boris Pasternak - a tradução de João Apolinário teve ampla circulação mesmo no Brasil quando foi trazida pela Edil em 1966 - somam-se 
como evidências exteriores favoráveis ao conhecimento de José Saramago sobre o livro quando escreveu o seu, pouco depois de uma década. Tudo o mais resulta das relações comparativas entre os dois livros, preservando cada qual nos contextos e inquietações que os motivam, o que permite, por sua vez, compreendê-los irmanados por naturezas criativas semelhantes. A partir desse diálogo estabelece-se a própria leitura sobre $O$ ano de 1993 como um livro, qual o do escritor russo, que é a um só tempo celebração e chamado à revolução, registro das transformações coletivas e reparo sobre as mobilizações no interior da subjetividade que impelem os indivíduos para a liberdade.

Boris Pasternak tem apenas quinze anos quando estoura o grande acontecimento do ano que dá título ao seu livro: insatisfeitos com a aristocracia czarista, vários setores sociais iniciaram uma sorte de movimentos cujo intuito é o enfrentamento de um regime centrado no mando e na exploração. Em $O$ ano de 1905, o escritor russo desenvolve cronologicamente no tempo, mas não na forma linear, os acontecimentos do que ficou sendo para a história a primeira tentativa de uma revolta proletária no século XX a partir do estabelecimento dos principais setores sociais: os camponeses, os operários, os marinheiros, os estudantes, as mulheres, resultando disso a formação dos primeiros sovietes, ajuntamentos constituídos por trabalhadores que a partir da Revolução de 1917 passam a desempenhar um papel essencial na organização social como a função de órgão deliberativo.

O ano de 1905 é para ser lido como um só texto. Seu autor diz em 5 de janeiro de $1926 \mathrm{em}$ carta a Marina Tsvetáieva que "Não é um poema, e sim uma crônica em versos. Escrita em sequência cronológica na forma de quadros separados" (Pasternak apud ROSAS, 2018, p. 123) - o que não é bem verdade. $\mathrm{O}$ episódio histórico é acompanhado por um olhar de cronista, um poeta capaz de captar o bulício das ruas, o estopim das bombas, o vozerio das gentes que lhe chega por fragmentos. Os sete poemas que dão forma ao livro configuram quadros, cada qual testemunha do andamento ou dos principais momentos da revolta, mas não são objetivos; o poeta interpõe digressões que apontam para reminiscências históricas e recordações da infância que participam ora de testemunho sobre a vida anterior à revolução ora atribuem um traço lírico aos acontecimentos.

O poema de Boris Pasternak se desenvolve rente à história sem se interessar, no entanto, em ser uma retomada pura e simples dos acontecimentos. Assim, o poeta pratica um transmudar para a constituição de uma metafísica como quando se utiliza de certa grandiosidade épica para imprimir alguns dos episódios como se verifica no relato sobre o Potemkin em "Revolta no mar". Por vezes, prevalece um envolvimento idealista com a revolução, certo traço adolescente e romântico do sacrifício como redenção do homem e da luta como alternativa à revisão da história, um gesto que julga indispensável à memória dos que tomaram para si o enfrentamento para a transformação do mundo tal como prenuncia no primeiro poema de $O$ ano de 1905, um texto cuja função ou sentido remete para a de uma dedicatória ou síntese do livro e reverbera no poema seguinte propositalmente intitulado "Os pais". Aqui, o passado mais profundo se nota como através de um sonho; o poeta assume-se em trânsito por um momento da história que se confunde com situações vividas na sua própria e acomodada infância.

Poeta da contiguidade, como determinado por Roman Jakobson (1987), as imagens sugeridas pela sua poesia são produzidas como resultado da disposição aproximada de objetos que se contaminam e foram outro objeto. "A cidade se tornou escultura do trabalho", retomando um verso quase final de "Os camponeses e os operários da fábrica" que oferece uma síntese própria da poesia de Pasternak e uma abertura para o diálogo com $O$ ano de 1993, um texto que parece conversar de frente para o seu antecessor mas atento a outros interesses, porque seu autor propositalmente manipula os sentidos não apenas em nome do seu contexto como interessado em tornar seu texto em objeto autônomo em relação ao plano histórico a que se refere. No caso do escritor português, a cidade é tornada em abrigo da dor e do horror. Sequestrada 
por um poder inominado e onipresente, todo esforço para sua retomada se procede pelas margens, por tentativas, até se encontrar o desmantelamento do seu núcleo. A cidade de Pasternak é, no entanto, posterior à cidade recuperada de Saramago.

Sempre referido pela aproximação e mesmo integração ao rol dos textos distópicos, $O$ ano de 1993 é um texto-problema no amplo debate sobre as feições da forma literária. A questão - embora pareça menor no interior das discussões e do interesse propostos nesta leitura e mesmo porque não é das mais importantes para escritores em livre experimentação como é o caso de José Saramago neste período - uma vez mencionada, e porque parece sem solução aparente, ou pelo menos cobra de cada leitor uma posição a fim de só então se disponibilizar à leitura, parece então necessária. Passemos por ela e encontremos nossa própria uma alternativa. Avancemos, então.

Há pelo menos duas filiações distintas. A primeira, como poema. Maria Alzira Seixo, embora ressalte que "há um fio narrativo sensível ao longo do livro, com movimentos de progressão e clímax que apontam para uma urdidura novelística", que, mesmo que nenhum subtítulo, como é recorrente na obra do escritor, "o integre num género literário determinado" parece se dispor a compreendê-lo como um poema, por ser este um texto no qual o mundo entrevisto pelo criador "não é aqui abordado enquanto circunstância efectiva mas como formulação poética literal" que "adquire uma significação humana, não só pela mensagem de conhecimento que se procura transmitir, mas também pela irradiação semântica multivalente que a criatividade verbal produz nos efeitos criados pela sua leitura." (SEIXO, 1987, p. 22-23). O poema assumiria, assim, as feições epicizantes no sentido do que foi atribuído à Mensagem, de
Fernando Pessoa. Se estirarmos o fio das relações, este texto se irmana também a Os Lusíadas, de Camões, ao cantar os feitos de uma gente portuguesa que reviu as linhas do destino, quando todos padeciam condenados à sorte semivariável do tempo. Entre os leitores deste livro no rol da poesia, está o próprio escritor; anos mais à frente das observações de Maria Alzira Seixo, ao organizar sua poesia completa, acrescentou $O$ ano de 1993 e esclarece que as raízes, como aferidas pela crítica, estão assentadas nos referidos poemas de Provavelmente alegria ${ }^{4}$.

Uma segunda possibilidade filia o livro de 1975 no rol da prosa-poética. Para Horácio Costa, este é um texto experimental como incorre noutras criações de José Saramago no instante de viragem para o uso da prosa romanesca como campo de atividade literária. Quanto à matéria, este livro de fragmentos (o estudioso evita o termo poema assumido pelo escritor) é futurante-distópico, pelas filiações que anteriormente apontamos: "o assunto tratado traduz as peculiaridades de uma distopia futura e a problematização metafórica e crítica do mundo que lhe deu origem, isto é, um mundo no qual tem lugar a escrita das mesmas obras que lemos [as da ficção científica]" (COSTA, 2020, p. 193). Para ele, o escritor funda a estrutura formal de seu texto na "utilização da estética do fragmento" e seu interesse está ativar as múltiplas camadas "do sentido na obra literária".

Boris Pasternak disse que o seu $O$ ano de 1905 era uma crônica em versos escrita em sequência cronológica na forma de quadros separados; essa definição, casualmente, nos propõe uma síntese das duas proposições levantadas. Se no primeiro caso é a aproximação com o acontecimento da história a determinante, no segundo também e a abertura que o tom inventivo imprime para o futurante. No caso

\footnotetext{
${ }^{4}$ Trata-se da publicação em língua espanhola Poesía completa, única antologia até o presente que organiza a biblioteca de poesia saramaguiana formada pelos livros Os poemas possiveis (1966), Provavelmente alegria (1970) e O ano de 1993 (1975), este último designado pelo escritor como um livro filiado às aberturas introduzidas com alguns textos da antologia anterior, quais sejam a aproximação entre poesia e prosa, o uso do versículo como célula rítmica e melódica; José Saramago descreve no prólogo oferecido exclusivamente para esta poesia completa que o livro de 1975 é composto por "trinta poemas de extensão variável que descrevem, com estilo ao mesmo tempo realista e metafórico, a terrível ocupação de um país por um invasor cruel, ambos não nomeados, até à libertação final” (SARAMAGO, 2005, p. 12, tradução minha).
} 
específico do escritor português, há uma relação que ficou ignorada até o momento nas discussões sobre este texto e oferecida logo na entrada de seu livrinho de versículos. Antes, pensemos, pelo conteúdo e pela forma, na possível retomada por este livro de O livro vermelho, de Mao Tsé-Tung: esta é uma coletânea de citações do presidente da República Popular da China com o intuito de difundir suas ideias e nelas educar o seu povo. Ora as similitudes entre esses livros são explícitas sobretudo quando reiteramos o contexto da revolução democrática e socialista situada nos bastidores de sua composição e a transformação do livro chinês a partir do final da década de 1960 num ícone da cartilha socialistamarxista ${ }^{5}$. Voltemos a $O$ ano de 1993.

As duas epígrafes são indispensáveis para a aceitação deste livro como uma crônica sobre a revolução e sobre os tempos de sua gesta. A primeira é da pena de um dos mais importantes cronistas portugueses, Fernão Lopes, e diz sobre o valor de verdade do que se escreve, mesmo se o que se conta pareça mentira. É um excerto que parece justificar o valor e a natureza do que vem a seguir, afinal, embora o livro trate de uma panaceia episódica, seus fundamentos se assentam no conteúdo da história, um tratamento voltado para a verdade do acontecimento e que se nota recorrente em parte fundamental da prosa ficcional do escritor português, reincidindo, em alguns casos específicos, no relato episódico-factual, matéria da crônica, como em Memorial do convento e em $A$ viagem do elefante, para citar dois exemplos dos mais singulares no seu projeto literário.

A segunda epígrafe é retirada de Jacques, o fatalista e seu amo, de Denis Diderot, um relato que expõe as muitas experiências vividas pelas duas personagens que emolduram seu título. Esta é importante ser transcrita porque os temas discutidos pelo pensador francês neste romance são fundamentais na compreensão do livro de José Saramago. "Mas quer me parecer que tua voz está menos rouca e que falas mais livremente"6 - é uma fala do amo no longo diálogo com Jacques sobre seus trânsitos amorosos pelo interior da França no século XVIII. A publicação desse livro ocorre também num instante de revolução: em 1796, a luta entre as elites e as massas populares dá início a um longo período de radicalizações que findaria com o 18 Brumário do ano VIII, "quando é denunciada uma suposta (ou real) conspiração jacobina e Bonaparte assume plenos poderes 'para garantir a segurança da representação nacional" " (ROMANO, 2006, p. 18). Das várias observações sobre o livro de Diderot em questão, estão o seu caráter radical de sua atividade literária apoiado no fragmento e na ampliação das contribuições criativas que o antecedem; "Diderot inventa novos textos e sentidos a partir do empréstimo aos textos e técnicas existentes. Ele opera como artesão da escrita, não como o suposto gênio criador, mito por excelência do romantismo." (ROMANO, 2006, p. 44). Nesse sentido, para além do efeito casual que unifica pelo tema os dois livros em relação, a epígrafe em questão esclarece o princípio criativo que orienta o escritor na feitura de $O$ ano de 1993.

As bases às quais se filia José Saramago são as mesmas do pensador francês - contra o idealismo e contra o finalismo, traços brevemente notados em Pasternak, embora neste, e falamos do autor de $O$ ano de 1905, não prevaleça de nenhuma forma os princípios do gênio romântico. Os dois livros agora em análise são uma reivindicação da

\footnotetext{
${ }^{5}$ A aproximação é levantada outra vez, por uma das razões que relacionam $O$ ano de 1993 e $O$ ano de 1905: a comunhão de José Saramago com o ideário intelectual do socialismo marxista, ideologia cuja aproximação se manteve em acentuado calor nos anos de quando aparece o livro de 1975. Uma das vertentes experimentais recorrentes na literatura saramaguiana deste período - e que se estenderá por toda a obra adiante - é a retomada pelo viés literário de porções textuais integradas a outros meios sobretudo se populares, como é caso a revisão de provérbios de corte aconselhador, de acontecimentos da história portuguesa, de mitologemas da cultura e de expressões ou passagens dos textos bíblicos. Sem o caráter imperativo do livro de Mao, $O$ ano de 1993 se organiza em torno de um conjunto de temas comuns: a luta de classes, guerra e paz, disciplina e trabalho, estudo e revolta. 1993 é testamento e um tipo de cartilha pró-Revolução.

6 "Mais il me semble que ta voix est moins rauque, et que tu parles plus librement". A tradução citada no texto é de J. Guinsburg (DIDEROT, 2006, p. 324).
} 
liberdade, numa dimensão metafísica no primeiro e materialista no segundo. Muito embora, neste último o que se pratica é um pastiche da apologia ao fatalismo de Diderot. À maneira da cartilha marxista, todas as opressões, no meio social, existem para resultar na revolução; o princípio é fatalmente questionável tantos anos depois, mas não esqueçamos que Saramago e Pasternak encontramse limitados pelas forças de seu tempo: o primeiro testemunha o nascimento das teses de Marx; o segundo vivencia suas práticas. $O$ ano de 1993 chega a repetir o que se designou com os levantes de 1905: as lutas espontâneas que se radicalizam ao ponto de fundar um movimento coletivo de desmantelamento do poder dominante, passando pelo confronto com o regime de domínio. Nesses dois livros o que se observa é a própria dinâmica da sociedade pela luta de classes, sendo esta formada a partir do movimento de exploração capitalista: um grupo oprimido se unifica em torno de um mesmo pensamento de resistência. Para o materialismo, o mundo social, a partir dos acontecimentos pretéritos transforma o mundo natural. E é assim que os dois novos mundos se possibilitam em $O$ ano de 1905 e $O$ ano de 1993.

Os autores dos dois textos exercem dois movimentos opostos: o primeiro, parte do plano individual e subjetivo, como é recorrente na poesia lírica, para alcançar o histórico; o outro, por sua vez, parte da história para alcançar o objetivo. Nesse sentido, $O$ ano de 1905 consegue ser um poema em que a ação é sempre interceptada pelo verbo plasticizante; "Estudantes", por exemplo é um dos poemas que mais avança nesse sentido; pelo uso do recurso da fragmentação determinante no segundo livro, o poeta capta os instantâneos do movimento da revolta. Depois, como já ficou dito, o livro de Pasternak é poesia tendendo à prosa, uma vez que há um fio de continuidade que alinhava os sete quadros, partes de uma mesma imagem. Nesse sentido pictural, este é um grande painel de tendência realista sobre o evento a que se refere. Enquanto isso, $O$ ano de 1993, prosa tendendo à poesia, é um imenso caleidoscópio, que, incapaz de oferecer uma imagem realista sobre o evento que ainda não veio se permite ao critério fabulatório do mundo possível ${ }^{7}$. Apesar das tantas relações com os cenários da ficção distópica, o relato resulta numa transição entre a grande noite e a utopia, o que leva Horácio Costa reparar que a vinculação com tais obras dessa linhagem da ficção científica “dá-se antes no nível difuso da matéria literária, no ponto de vista moral ou ético que maneja o autor em relação ao mundo em que vive através do espelhamento deste num futuro determinado pelas vicissitudes do presente" (COSTA, 2020, p. 193) e não no nível da forma.

O ponto de vista sob o qual se desenvolve as situações em $O$ ano de 1905 é o de um adolescente, para quem a história é um marasmo sem fim de repetições, num país de gente submetida às engrenagens mortais de um poder. No outro livro, uma voz descarnada e sentenciosa coordena o relato; está aqui um protótipo do narrador tipicamente saramaguiano desabrochado a partir de Levantado do chão. Essa voz apenas descreve como se buscasse compor uma imagem total do que vê, como se um espectador diante do grande painel pintado por Boris Pasternak. Mas, o que nos oferece, ao invés da descrição realista é uma interpretação fragmentária, como se o seu mecanismo de ver estivesse de alguma maneira avariado pelas próprias condições do mundo que descreve. Impossibilitado de dizer as coisas como são, se põe a contá-las por imagens alucinadas, e dizendo não diz, sugere. As relações que estabelece com a pintura surrealista

\footnotetext{
${ }^{7}$ Esta observação contradiz abertamente a compreensão oferecida pelo próprio autor, para quem, $O$ ano de 1993 é "ao mesmo tempo realista e metafórico" (SARAMAGO, 2005, p. 12, grifo nosso). Sem estender um debate mais que secular e nunca esgotado em torno da expressão em destaque, o entendimento de estilo realista do escritor é precipitado: a tendência primordial para tanto, a representação do acontecimento não se verifica em nenhuma das trinta estações do texto. Pelo contrário, o episódico é invadido e modificado até o limite da sua deformação, propondo multiperspectivas sobre o conteúdo do relato. A única possibilidade de aproveitamento do termo realista para com este livro se refere ao elemento pictural: cada fragmento insinua uma imagem em multiperspectiva sobre mundo onde o sentido original aparece afetado pela ausência de originalidade.
} 
de Salvador Dalí, expressa logo à entrada do texto, e que poderíamos facilmente estendê-las com a pintura do italiano Giorgio de Chirico ou as visões alucinadas de Hieronymus Bosch, não são, como nada é neste e noutros textos, pura menção. Utilizando-se da aproximação com o visual - uma constante fundamental na literatura de Saramago - o escritor consegue expressar mundo de $O$ ano de 1993.

Todo enredamento possível está oferecido pela linha do embate, não necessariamente dicotômico, cuja base é a pueril constituição bem e mal; nesse sentido o mundo entrevisto se faz com as mesmas tintas visionárias do Apocalipse. Reside aqui a natureza das múltiplas camadas de sentido para o que se conta: homem e Deus; homem e natureza; homem e sociedade; homem e poder; homem e história; mundo primitivo e mundo moderno; opressão e revolução; totalitarismo e liberdade; passividade e ação; luta de classes. Estas e outras, determinam, portanto, as leituras possíveis deste livro e a mais cômoda talvez seja a que vimos perseguindo que trata de conjugar a matéria ficcional com a histórica. O cenário de 1993 é propriamente apresentado com a metonímia de uma situação de proporções extremas. O que cada fotograma nos revela é um mundo virado pelo avesso.

Dentre as várias tentativas para o estabelecimento do fio narrativo neste livro, pode-se primeiro compreender que estamos diante uma cidade sitiada por uma peste e sob o mando de homens e animais em que outra parte das gentes lhe são barganha, habitantes clandestinos, permitidos para servir sua carne ao grande computador central e de peças do infinito tribunal em praça pública que interroga e castiga sob o mando de um feiticeiro capaz de transformar por instantes a cidade em corpo humano para o açoite - outra vez, falsamente libertas, as pessoas, mesmo que marcadas não se reconhecem vitimadas do gesto. Além da não tão variada fauna de peçonha que cuida religiosamente das três sessões noturnas de recenseamento (ratos, cobras e aranhas), chama a atenção que essa condição se determine em parte por uma revolta dos animais domésticos, como o macaco de estima que crucifica a dona, e mantenha sob a vigilância dos lobos; são eles os principais habitantes da cidade e, com isso, logo reencontramos o princípio filosófico que, afinal, é outra chave para a fábula deste livro: "O homem é o lobo do homem". A sentença do dramaturgo Plautus tornada célebre com a reescritura de Thomas Hobbes é a um só tempo eco e dorsal da imaginação literária. O autor de Leviatã conceituou-nos como naturalmente egoístas e maus o que nos revela enquanto ameaça para nós mesmos - visão compartilhada pelo próprio José Saramago; assim, esses lobos muito apropriadamente designam os conturbados tempos de intermitência, marcados pelo conflito e a violência do homem contra o homem, e a incapacidade fatalista de, sabedores do fim, não alcançarmos a utópica saída que nos coloque fora dele.

Os homens-toupeira descritos em $O$ ano de 1993 comparecem antes nas imagens oferecidas pelo poema "Os camponeses e os operários das fábricas", de Boris Pasternak. Este poema inicia com uma descrição do começo do ano de 1905; e nele encontramos que "Colocando o seu capuz / O país dorme, saciado, / Como uma marmota" (PASTERNAK, 1966, p. 45). No primeiro, abre-se uma leitura muito cara ao pensamento saramaguiano: a cegueira. Os que se adaptaram a viver sob o chão, sofrem, diz 1993, "de limitações físicas semelhantes" à toupeira: "Custar-lhes-ia provavelmente distanciarem-se do sol / Caso em que teriam muito mais razão do que a toupeira que é cega ou quase e o homem não ainda que nesse sentido tenha feito alguns progressos" (SARAMAGO, 2007, p. 42). A cegueira evocada reafirma o tempo anterior à revolução: marcados nos dois textos pela aceitação passiva do curso natural do tempo, pela impossibilidade de ver e a oclusão. Esses homens, no universo visionário de Saramago, incapazes de cavar para baixo, são propriedades de caça dos que vivem à superfície: "Uma lança cravada a pique ou uma estaca trespassam pelas costas o homem de unhas longas e coragem insuficiente" (SARAMAGO, 2007, p. 43).

Também Pasternak move-se nesse subsolo feito de mortos que é a materialidade da história. 
Seu poema, à maneira da descida de Petrarca aos infernos, é sua tentativa de desenterrar uma Rússia subterrânea, tal como observa Benjamin Goriély, neste círculo, reencontra os populistas dos anos 1860-80, os niilistas, reconhece Dostoiévski, "vê as sombras dos militantes da Naródnaia vólia, a inesquecível Vontade do Povo dos anos 80"; nesse reencontro, o poeta ressuscita "aqueles que sacrificaram todas as suas forças intelectuais 'esquecendo, em nome do ideal, todos os laços e parentesco e simpatias pessoais' de harmonia com os termos do estatuto" (GORIÉLY, 1966, não paginado); eterniza a gente que foi enforcada, agrilhoada, presa para toda a vida nas células dos condenados à morte, torturados, deportados, exilados. Esse resgate oferece-lhe o tom épico do seu poema da mesma maneira que em $O$ ano de 1993 se reanimam a coragem, a luta e o grande esforço de resistência e coalizão contra o poder dominante, distinguindo-se, portanto, e ampliando os sentidos da Mensagem, em que o epicizante ainda eram as descobertas, os bons-feitos, portugueses.

Tudo no universo de 1993 remete ora para os estados ditatoriais e os totalitarismos do século XX: a prisão, o interrogatório, a tortura, os silenciamentos, o estupro (tantos que já se designam como entregas), os cerceamentos, as conversa cifradas (figurativizada pelo texto em sua própria forma), o desparecimento dos corpos sob as sombras, a vigilância onipresente por pequenos olhos vermelhos que seguem as pessoas aonde forem, a guerra, a miséria, a peste, os campos de concentração, a mortandade. Pasternak ainda não testemunhara parte desse horror quando cantou a Revolução de 1905, assim, apenas a opressão e suas derivações se mostram nos poemas; estas aparecem transmudadas na perenidade e impassibilidade, na perspectiva do que é o tempo para a criança, mesmo ar que compõe a atmosfera do texto saramaguiano, mas aqui tudo está à maneira de uma pintura de Salvador Dalí. A revolução é uma esperança para o primeiro; para o segundo é uma possibilidade necessária antes da total danação, quando, a possibilidade do suicídio coletivo se constitui para o povo de 1993 em decisão premente.
O estopim da revolução não significa apenas uma mudança das coisas; é o instante aberto para um futuro. A revolução é uma "abertura de uma sociedade para todas as suas possibilidades" (FURET, 1989, p. 61); "a promessa tão vasta" que "tem um nascimento, mas não um fim" (FURET, 1989, p. 17). Assim, o tempo de opressão é também o de longa reaprendizagem do mundo; no caso específico do texto de Saramago, esse processo inclui outra / ou uma leitura sobre as coisas. A descoberta da palavra (como se agora se retomasse a descoberta da linguagem no mundo primitivo) é a principal das descobertas para a revolução, ou mesmo, a própria revolução. Orientado pelas premissas do marxismo, o escritor sugere que uma renovação do mundo começa (e só é possível) por uma compreensão dos sentidos mediados pela palavra: "Não admira que fosse preciso reaprender a linguagem simplificada da fome e do frio / E também as palavras da manhã e da noite e aquelas que determinam no céu o caminho das estrelas ou apenas o perfil da montanha", registra $O$ ano de 1993 no instante de viragem radical da condição dos subjugados, "Porque se sabiam as sensações e não as palavras que as tornavam úteis no comércio ou simplesmente suportáveis" (SARAMAGO, 2007, p. 85). O renascimento da linguagem sustenta-se numa compreensão original nascida entre os antigos hebreus, em que o ato de nomear significa "dar às coisas a sua verdadeira natureza, ou reconhecêla" - princípio que é o fundamento da linguagem (BOSI, 2000, p. 163).

Na leitura sobre $O$ ano de 1993, Américo António Lindeza Diogo compreende que este livro é também o "contar de uma perda da linguagem que é uma nítida perda do humano da linguagem" (DIOGO, 1999, p. 68). Ora, novamente ressaltando o aspecto formal que faz deste um texto-em-si de reaprendizagem, a voz que narra parece então não se encontrar de um todo apartada dessa coletividade em ruína observada através de seu monóculo com palavras; por tentativa, ela própria encarna o drama de 1993, o de recuperação de humanidade perdida e não há outra possibilidade da história sem existir outra possibilidade de contá-la - paradigma 
fundamental para toda a obra saramaguiana. A mesma preocupação se verifica no jovem Pasternak, conforme se nota na intercepção do tecido poético por elementos da prosa narrativa ou ainda a aproximação com as vanguardas, explicitamente o futurismo de Vladmir Maiakóvski ${ }^{8}$.

Observamos anteriormente como o poeta russo organiza as parcelas que constituem os quadros da Revolução de 1905. Entre suas escolhas no reconhecimento do passado revolucionário não podemos deixar de sublinhar o grande protagonismo que atribui às mulheres; como que envoltas pela bruma de um tempo imemorial, prontas a quaisquer renúncias, é delas o impulso para a força, são elas a luz do longo calvário do movimento revolucionário na Rússia do final do século XIX; assim registra o poema "Os pais": "Quanto a estas mulheres votadas à reclusão, / Não esperando / Que, para elas, / Cada investigação / Fosse uma transferência de relíquias para o museu / Iam para a fogueira / Preparadas / Para que o clandestino Nechaev / Enterrasse a sua beleza na terra, / Ocultando-a / Quer aos amigos, quer aos inimigos" (PASTERNAK, 1966, p. 32). Uma única figura feminina se apresenta em todo o poema, mas ela se assume como síntese de todo o evento histórico recordado: Sofia Perovskaia. Mentora do assassinato do czar Alexandre II, ela foi ainda a primeira mulher executada na Rússia no tempo quando os radicais czaristas não conseguem conciliar a imagem comum da mulher votada à reclusão com suas atividades para a violência. $\mathrm{Na}$ leitura sobre a presença feminina na poesia de 1905 e nos alvores da revolução, Benjamin Goriély confirma a mulher revolucionária como a devota de um "sacrifício total": "A atividade, os pensamentos, as paixões destas mulheres votadas à reclusão devem gravitar em roda de uma única ideia: a revolução. Uma única lei: a destruição total e implacável, da sociedade. Uma única moral, a que serve a causa" (GORIÉLY, 1966, não paginado, grifo do autor).

A fúria da mulher revolucionária aparece entre os primeiros movimentos de retomada da cidade sitiada de 1993. Se Pasternak convoca o passado místico-lendário de sua cultura para compor sua figuração, o escritor português recorre a um imaginário medieval popular recorrente em várias culturas e tornado rica fonte entre os surrealistas pela estreiteza com o primitivo do homem e suas sugestões oníricas; neste caso, a reiteração do mito parece se estabelecer a partir de uma aproximação com os afluentes do realismo maravilhoso, o que é verificável em vários outros momentos da literatura de José Saramago. No novo mundo, o da utopia, posterior à ocupação, o escritor revisitará outra vez a bateia desses signos ao propor a imagem da longa fila de mulheres a regar a nova terra para cultivo com o sangue da menstruação. No primeiro momento, é o mito da vagina dentada; o ajuntamento de mulheres, prontas para o assalto coletivo dos corpos, que se oferece aos perseguidores:

[...] e no exacto instante em que o espasmo militarmente iria deflagrar / Com um estalo seco e definitivo os dentes que o ódio fizera nascer nas vulvas frenéticas / Cortam cerce os pénis do exército perseguidor que as vaginas cospem para fora com o mesmo desprezo com que os homens perseguidos haviam sido degolados (SARAMAGO, 2007, p. 35) .

\footnotetext{
${ }^{8}$ Esta constatação é visível a partir do que observa Cecília Rosas em estudo uma vez referido neste texto; amparando-se em Lazar Fleishman, no seu estudo Boris Pasternak. The poet and his politics (Harvard University Press / DeGruyter, 2014), a autora diz que, como um defensor da intelligentsia, "Pasternak tinha nessa época uma visão do lugar do poeta na sociedade bastante calcada nos ideais pré-revolucionários. Questões como o lirismo, a individualidade e a auto-consciência foram centrais nas suas obras de juventude"; e registra que o poeta, mesmo reafirmando constantemente sua independência, quando de sua consagração literária, "estava ligado ao grupo dos futuristas, com quem mantinha uma relação muito próxima. Além disso, por toda a vida teve profunda admiração por Maiakóvski, a quem dedicou diversas obras." (ROSAS, 2018, p. 9).

${ }^{9}$ Conforme observamos em Retratos para a construção do feminino na prosa de José Saramago, este instante é retomado por José Saramago mais adiante, no romance Ensaio sobre a cegueira; o episódio designado também por um estupro coletivo comandado agora por um grupo de cegos que determinam suas próprias leis de apropriação do espaço manicomial onde estão recolhidos para cumprirem uma severa quarentena devido à epidemia de cegueira branca. É sintomático que às mulheres sejam delegadas funções de libertação. E não apenas pela coincidência nominal e poética do termo revolução. Prevalece um entendimento de que as transformações almejadas pela revolução passam necessariamente pela descontinuidade de um mundo onde as bases foram determinadas pelo masculino. Assim, quaisquer alternativas que visem suspender as ameaças ao programa civilizatório devem passar pela horizontalidade dos seus elementos comuns, sem a sobressalência de uma outra determinante.
} 
A revolução possível de José Saramago é tão proletária quanto as bases fundamentais da Revolução Russa de 1905 cantada por Boris Pasternak; reveste-se mesmo de certo messianismo. A principal dicotomia que se amplifica ao longo do texto é a assumida entre o campo e a cidade. Os enjeitados pelo grande centro do totalitarismo a ele retornam depois da aquisição de uma nova linguagem, o que os permitem encontrar as lacunas do sistema de mando; esses homens e mulheres também participam de uma longa aprendizagem com a natureza adquirida, ao que parece, do convívio com as grandes estátuas que viviam uma condição que os homens poderiam um dia ter alcançado, reativando relações de pertença destituídas desde a descoberta do conhecimento. Esse movimento circular pressupõe as diretrizes do tempo histórico, naturalmente contínuo e repetível como manifesta a variedade de trocas das posições categoriais entre os 57.229 habitantes no sistema da cidade de 1993, sem que estes saibam. Na aproximação com o discurso bíblico, o texto perfaz o conceito segundo o qual os humilhados serão exaltados. A revolta, cujo ponto de princípio é a dissidência, se manifesta como o artefato necessário para que essa variação não repouse ao sabor da natureza, se isso fosse possível. Na revolução reside a capacidade do homem fazer-se senhor de seu tempo - para mal ou para bem. Na tribo, o ajuntamento periférico de resistência, o que aprendeu a ler, possivelmente, é o que se afasta do grupo para a ele retornar, qual Prometeu, com o fogo do conhecimento e juntos ensaiarem a tomada final e o desfazimento do tempo de opróbrios; desde 1993, seus habitantes se deixam pensar sobre os episódios que estão na base dessa transformação cem anos depois, o ano de 2093. Assim, o tempo da revolução é sempiterno, adiado ou adiantado conforme os itinerários de reparação da coletividade e restauração do futuro.

Em $O$ ano de 1905 todo o futuro é rasurado em pleno movimento, o instante quando finda o poema de Pasternak, mas, sabe-se que tudo depois de um terremoto histórico jamais será o mesmo que antes. O desfecho da crônica de Saramago, por sua vez, se permite reimprimir o mitologema do nascimento como o prenúncio da esperança; o instante posterior ao da reconquista da originalidade apagada e apagamento do desencanto se coroa com os traços do que alguns numa leitura apressada tratariam como produto de um messianismo cristão. Até poderá ser. A redenção, entretanto, é bifronte. No princípio da revolta, uma imagem não pode passar desapercebida; o instante de ódio coletivo das mulheres não chega para todas. Entre elas, uma recolhe o pênis no momento posterior a ejaculação e afasta-se da tribo; essa dissidente, ao contrário do homem-Prometeu que retorna aos revoltosos, some no horizonte do texto. Mas, ainda que apenas o jogo interpretativo permita essa leitura (este é um texto feito por justaposição), a criança que reabita o novo mundo pode ser filha do mal e de um engano. De toda maneira é um fim inaugural. Quer dizer, repete-se pela forma a própria espiral da história ao abrigo dos mesmos ventos do acaso e da atividade humana.

\section{Conclusão}

Se voltarmos à segunda epígrafe de $O$ ano de 1993 para estabelecê-la como paradigma de leitura do livro de José Saramago, podemos compreender que esta é uma crônica sobre a liberdade; sem desprezar as influências do marxismo para a formação do pensamento do escritor português, ser livre pressupõe conhecer o funcionamento das leis da história a fim de modificá-la pelo uso dessas mesmas leis. A liberdade consiste em saber decifrar os sinais emitidos pela história, o que, numa sociedade dominada pela técnica e pelo totalitarismo, como a propositalmente forjada pelo cronista, se mostram a olho nu. O livro resolve o impasse entre o mundo livre e o fatalismo a que estaríamos condenados; o mundo de 1993 esclarece a liberdade como um meio e não um fim, como parece se ver no canto de Pasternak à Revolução de 1905. Isso significa dizer que um dos princípios que determinam nosso lugar no mundo é a ação para a liberdade e não a fuga de um destino que, cedo ou tarde, chega para todos; a ação é nossa única possibilidade de alterar o curso do acaso e 
da fatalidade. Isso implica um compromisso com os do passado, do presente e, consequentemente, do futuro.

Ao compreender essas implicações no marxismo de Marx, numa interpretação das bases que fundamentam o materialismo do Diderot de Jacques, o fatalista, Roberto Romano esclarece algo que tomamos como fundamental na ruptura com o mundo em desencanto ficcionada pelo cronista de 1993: a passagem entre homem e natureza. O mundo é resultado da simbiose entre o homem e a natureza, traduzida em $O$ ano de 1993 pela imagem surrealista do homem-mulher-árvore - "Então abraçados o homem e a mulher sem uma palavra suplicaram / E a árvore a que se apoiavam transidos abriu-se por uma qualquer razão que não veio a saber-se nunca e recebeu-os dentro de si juntando a seiva e o sangue" (SARAMAGO, 2007, p. 81). Parafraseando-o, o mundo reinventado é uma operação do corpo humano modificado em relação ao animal pela arte e pela técnica. É nesse sentido que se realça a distinção entre homens e bichos no mundo de 1993 pelo plano da consciência. O cérebro é a matéria paralisante do grande computador central que controla o estado totalitário da cidade. Os homens da urbe tornados bichos são também uma involução pela ausência de consciência. E provém da tomada de consciência a possibilidade da revolta, a propulsora de um mundo emergido como resultado da representação. Assim, qual Marx, "o ideal (das Ideelle) nada mais é do que o material invertido e traduzido (überzetzte) na cabeça do homem" (apud ROMANO, 2006, p. 53); o homem saramaguiano - como para o filósofo alemão, e mesmo o cantado por Boris Pasternak - é um demiurgo, porque é um produtor de sua condição de existência.

A parábola de 1993 é um encalço sobre as certezas para as quais nos movemos: contra a certeza no transcendente, o acaso; contra este, a necessidade das leis naturais. A revolução supõe o possível porque feita das leis da natureza rompe com o fatalismo. Como para Diderot, o acaso tudo decide, ele é o campo de liberdade onde os homens decidem. "Quando não existe ciência e técnica e os homens ignorantes submetem-se a supostos caprichos divinos", destaca Roberto Romano, ou quando os homens "têm medo do aleatório e transformam o saber científico em âncoras e bússolas que garantem segurança no caos da natureza e das paixões humanas, surge a fantasmagoria do fatum, do destino." (ROMANO, 2006, p. 62). Romano, nessa mesma leitura de Jacques, o fatalista, esclarece que Diderot "mostra o absurdo da crença de quem ignora o Acaso e as leis do universo, a passagem permanente deste último do caos à ordem legal, e vice-versa, o que leva ao fatalismo e faz dos indivíduos marionetes sem impulso e desejo próprio." E acrescenta a desconstrução da "crença 'mais racional', de quem imagina o universo submetido a leis implacáveis, leis que retiram toda ação e liberdade dos seres humanos, ou seja, os reduz ao papel de marionetes de uma necessidade absoluta." (ROMANO, 2006, p. 63). É nesse sentido que para Diderot - e, por extensão, acrescentamos Saramago - o homem ideal é o que se alia ao homem-natural, razão e instinto, alma e corpo, o natural e o social. Quer dizer, a revolução, utilizada no seu sentido histórico pelos dois criadores lidos neste texto, é meio a partir do qual o escritor português formula uma ética do homem de ação; as imagens de 1993 descrevem a libertação, desde o sentido mais recorrente, homem-deus, isto é, a libertação do superior, do obscuro, do contraditório e dispensável, ao sentido de libertação do homem pelo homem, empregado por Boris Pasternak. Ora, essa leitura parece encontrar-se com a de Ana Hatherly, visto que, para ela $O$ ano de 1993 aponta para um futuro que se apresenta "como uma montanha de destroços que 'uma guerra do desprezo' não pode manter imóvel"; e acrescenta, "é uma montanha que é preciso mover, talvez com uma fé que ainda não ouvimos falar, uma coragem desusada, sem desgaste" (HATHERLY, 1976, p. 88).

Nesse sentido, é possível organizar os fragmentos que constituem o texto de Saramago em dois tempos: um anterior à revolução, marcadamente por um regime de horrores do homem escravo do homem (que podemos situar como o 
presente do texto); e outro posterior, de reabitação do mundo, confraternização da humanidade, do homem liberto do homem (um indeciso e aberto futuro). E a revolução? Em qual plano situá-la? Boris Pasternak a situa no campo da história; é o acontecimento feito pela ação do homem e manifesto fora dele, no mundo em transformação. José Saramago, fortemente influenciado (no sentido ideológico) pelo neorrealismo no seu país, por vez, imprime este (o levante popular) e outros sentidos, porque compreende que a ação pura e simples não oferece os resultados suficientes ${ }^{10}$. É nesse sentido que supõe uma revolução interior, dos saberes. A cidade sitiada de 1993 só alcança seu desmonte quando o sistema central que a mantém é infectado no seu interior. Essa possibilidade, obviamente, não deixa de ser aventada em $O$ ano de 1905, porque anterior à revolução está sua ideia, mas no seu contexto o novo homem nasceria com as bombas que rebentam. Há toda uma estética niilista belicista do futurismo que não faz mais sentido no mundo de 1993. No caso português, prevalecem aspectos do simbólico, do alegórico e do filosófico; já se sabe que a guerra é puramente destruição, desordem e morte, como revela o cenário reiterado da cidade sitiada, logo o novo homem nasce com a desconstrução do velho. Daí ser um movimento sempiterno, premente no próprio ato de existir, tomado aqui como prática e prova.

Não deixemos passar uma constatação que fizemos logo início deste texto que filiava $O$ ano de 1993 ao regime de uma parábola de feições apocalípticas. Quando agora reiteramos o encontro dos tempos - presente e futuro - é válido esclarecer um denominador comum que sustenta esse laço; Alfredo Bosi recorda que o sustento do imaginário profético e apocalíptico encontra-se justamente no "eixo presente-futuro com a sua vigorosa e concreta antinomia, pela qual o presente é o cenário da maldição, objeto de escarmento, e o futuro é antecipado pelo sentimento como o reino da justiça e liberdade" (BOSI, 2000, p. 189). É nesse sentido que o livro de José Saramago se faz peça dentro e fora da temporalidade da história.

Ao obedecer essa filiação, $O$ ano de 1993 se integra no imaginário propriamente português pela leitura sobre a reconquista redentora do mundo, muito embora, este não seja o mundo de fora como é para o tempo das grandes navegações e sim o de dentro, este que se encontra sob as rédeas de um fatalismo, uma vez que perduram a aceitação taciturna do mando e com ele toda sorte de imposições pela simples repetição caprichosa do designado. Neste mundo suposto o homem é a medida de todas as coisas; já não mentem os deuses quando dão porque sequer eles existem. José Saramago se apropria do ideário da revolução e ainda que permaneça estritamente ligado aos conceitos marxistas que se formulam a partir da Revolução Russa de 1905 (e daí sua estrita semelhança com o livro de Boris Pasternak) não está cerrado com seus sentidos; ao falar a partir da revolução fala sobre a luta do homem em dar forma e sentido ao mundo dentro e fora dele.

O totalitarismo de 1993 se mostra por esse nome - suas evidências são oferecidas porque as imagens são logo ativadas pela nossa memória histórica e um ou outro indício disperso no texto ou ainda o seu contexto: os horrores, centrificados como foram o nazismo e o socialismo soviético (que Boris Pasternak na sua juventude nunca previu por mais profético que tenha sido sobre todo o resto quando escreveu Doutor Jivago), ou não, são, infelizmente, parte constante da nossa história enquanto civilização. Para nossa sorte, as revoluções e o empenho para a liberdade, também. Logo, o que intrinsecamente se denuncia são os fanatismos de variada espécie, sempre capazes de induzir toda uma coletividade para o precipício ou lançar indivíduos uns contra os outros; o que se evidencia é que toda liberdade se constitui dos antecedentes naturais e históricos e estes últimos

\footnotetext{
${ }^{10}$ Horácio Costa, no já referido O período formativo, compreende que $O$ ano de 1993 vincula-se, no plano narrativo, "à retórica militante, redentorista, de certa poesia neorrealista" (COSTA 2020, p. 223); destaca entre essas retomadas a poesia de José Cochofel e Daniel Felipe. A essa forma-mentis do neorrealismo português, funde-se certo traço do alegórico pela "abertura semântica proveniente da utilização do imaginário e das informações plásticas surrealistas ou surrealizantes” (COSTA 2020, p. 226).
} 
se fazem da luta para reanimação da memória. Assim é que, toda tomada consciência (individual e coletiva) passa pela história e pela memória. "Não tem sentido falar em realidade em si, como é desprovida de significado uma liberdade sem antecedentes naturais e históricos" (ROMANO, 2006, p. 81).

São três os fios que interseccionados estabelecem um aspecto narrativo para $O$ ano de 1993: um discorre sobre o gradual processo de instauração da opressão; outro sobre as atividades do regime totalitário; e o nascimento subterrâneo da revolução, o instante que conduzirá todos para a liberdade. Cada um deles desfia-se noutros. Assim é que as práticas descritas se servem das recorrentes históricas dos poderes centralizadores nas ditaduras e nos variados regimes de mando; nas variantes de organização coletiva e ideológicas; e, por fim, os estágios para a revolução, do aparecimento da consciência às tentativas de derrocada do poder dominante, das revoltas à libertação. O aspecto parcelar da escrita, que nota uma crise da linguagem como observado aqui, esclarece ainda sobre como estão ordenadas as existências: natureza, história e humanidade existem tal como se revelam, caóticos. A ordem, repetimos a singular epígrafe de $O$ homem duplicado, é um caos por decifrar. Assim, se ela existe, é coordenada pela ação humana - experimentada in loco pelo tratamento surrealizante dado ao texto; o livro, como imagina Michel Foucault, "é evento minúsculo, pequeno objeto manejável" (FOUCAULT, 1976, p. 7-8), objeto para ser ampliado e manipulado à maneira do leitor.

No seu conjunto fragmentar e disperso, o livro consegue estabelecer uma forma circular. Nesse caso, a circularidade é manifesta não pelo retorno ao início do possível fio narrativo centrado já no tempo parado e de sombra do horror e da ocupação, mas ao tempo que antecede essa condição. Esse tratamento, não se permite ficar reduzido ao estrato de uma pura obsessão formal (devida a sua recorrência na prosa romanesca de José Saramago), porque à maneira da ordem fragmentária e caótica, participa na constituição de uma semântica total do livro. Dizíamos que esta crônica também se confunde, no aspecto estrutural com o tema recorrido. Assim é que se denota a história enquanto fluxo repetível, como averiguamos, e a inserção do texto na órbita do tempo mítico, uma vez que o que se conta, apesar de ficção, tem por efeito uma verdade sobre o coletivo, qual justifica a primeira epígrafe tomada de Fernão Lopes, além, é claro, do tom fabular de parábola assumido em como se conta, incluindo o versículo como forma de estruturação do texto.

O ano de 1993 é assim uma crônica-parábola sobre a múltipla natureza no homem, situada no intervalo das dicotomias que o define e concentrada na sua parcela sensível e primitiva que aspira à liberdade e se revolta contra as imposições e imposturas dos modelos de dominação estabelecidos pelo próprio homem arbitrária e artificialmente. A busca pela liberdade, situada entre a busca do natural e do espontâneo, é ainda uma busca por verdade moral só acessível a partir do despertar de uma consciência da história e da natureza, conforme designamos. Enfim, todas as diretrizes utilizadas no desenvolvimento de sua prosa romanesca estão contidas neste pequeno livro que não é, nem quis ser, documento ou testamento de um tempo. Como Dalí, o pintor dessa paisagem levantou um grande sol que continua para entre os dois deste céu. Ou seria qualquer fuga tal como as compostas há duzentos e cinquenta anos por "João Sebastião Bach" em Leipzig e que ainda se ouvirão duzentos e cinquenta anos depois e até quando durar os espíritos para as sensibilidades?

\section{Referências}

BOSI, A. O ser o tempo da poesia. São Paulo: Companhia das Letras, 2000.

COSTA, H. O periodo formativo. Belo Horizonte: Moinhos, 2020.

DIDEROT, D. Jacques, o fatalista e seu amo. Tradução: J. Guinsburg. São Paulo: Perspectiva, 2006. 
DIDEROT, D. Lettre apologétique de l'abbé Raynal à monsieur Grimm. In: CHOUILLET, J. Oeuvres de Diderot. Paris: Robert Laffont, 1995. t. 3 .

DIOGO, A. A. L. O ano de 1993: representação e poder. Provérbios. Revista Colóquio / Letras, Lisboa, n.151-152, p. 65-78, jan. 1999.

FOUCAULT, M. História da loucura. Tradução: João Teixeira Coelho Neto. São Paulo: Perspectiva, 1976.

FURET, F. A revolução francesa terminou. In: FURET, F. Pensando a revolução francesa. Tradução: Luiz Marques e Martha Gambini. Rio de Janeiro: Paz e Terra, 1989.

GORIÉLY, B. Estudo. In: PASTERNAK, B. $O$ ano de 1905. Tradução: João Apolinário. São Paulo: Editora Piratininga, 1966.

HATHERLY, A. J. S. O ano de 1993. Revista Colóquio / Letras, Lisboa, n. 31, p. 87-88, maio, 1976.

JAKOBSON, R. Language in literature. Cambridge: Harvard University Press, 1987.

PASTERNAK, B. O ano de 1905. Tradução: João Apolinário. São Paulo: Editora Piratininga, 1966.

PICCHIO, L. S. O futuro do passado: O ano de 1993, de José Saramago. Veredas, Porto, n. 3, p. 351-362, dez. 2000 .

ROMANO, R. Introdução In: DIDEROT, D. Jacques, o fatalista e seu amo. Tradução: J. Guinsburg. São Paulo: Perspectiva, 2006, p. 15-85.

ROSAS, C. O fio longo dos espaços: a correspondência entre Marina Tsvetáieva e Boris Pasternak (1922-1926). 2018. Tese (Doutorado em Letras) - Universidade de São Paulo, São Paulo, 2018.

SARAMAGO J. E immortale è la speranza. In: SARAMAGO J. L'anno mille993. Tradução: Domenico Corradini H. Broussard. Milão: Feltrinelli, 2012.

SARAMAGO, J. O ano de 1993. São Paulo: Companhia das Letras, 2007.
SARAMAGO, J. Levantado do chão. 12. ed. Rio de Janeiro: Bertrand Brasil, 2005.

SARAMAGO, J. O homem duplicado. São Paulo: Companhia das Letras, 2002.

SARAMAGO, J. A noite. In: SARAMAGO, J. Que farei com este livro? São Paulo: Companhia das Letras, 1998.

SARAMAGO, J. Ensaio sobre a cegueira. São Paulo: Companhia das Letras, 1995.

SARAMAGO, J. As últimas da escrita: um escritor não tem o direito de rebaixar o seu trabalho em nome de uma suposta acessibilidade [Entrevista concedida a] G. F. Extra, Lisboa, 1978.

SEIXO, M. A. O essencial sobre José Saramago. Lisboa: Imprensa Nacional, 1987. 
